\title{
Ceramic Ultra- and Nanofiltration Membranes for Oilfield Produced Water Treatment: A Mini Review
}

\author{
K. Shams Ashaghi ${ }^{1}$, M. Ebrahimi* ${ }^{* 1}$ and P. Czermak ${ }^{*}, 1,2$ \\ ${ }^{I}$ Department of Biotechnology, University of Applied Sciences Giessen-Friedberg, Giessen, Germany \\ ${ }^{2}$ Department of Chemical Engineering, Kansas State University, Manhattan, Kansas, USA
}

\begin{abstract}
Produced water is any fossil water that is brought to the surface along with crude oil or natural gas. By far, produced water is the largest by-product or waste stream by volume associated with oil and gas production. The volume of produced water is dependent upon the state of maturation of the field. There is a need for new technologies for produced water treatment due to increased focus on water conservation and environmental regulation. Each time regulatory agencies initiate more stringent environmental control treatment technologies are refined to meet the updated standards. The European standard for effluent from onshore petroleum activities requires less than $5 \mathrm{mg} / \mathrm{l}$ total hydrocarbons (HC) and less than $10 \mathrm{mg} / \mathrm{l}$ suspended solids; such low concentrations are unattainable when classical separation processes are used. To overcome the challenges posed by more stringent regulations, operators have turned to membrane filtration schemes which have the potential to minimize additional costs and disposal issues. Ceramic ultra- and nanofiltration membranes represent a relatively new class of materials available for the treatment of produced water. They can be manufactured from a variety of starting materials and can be processed in different ways to yield products with broad ranges of physicalchemical advantages and applications. While these membranes are effective in the separation of oils, emulsions and silts, they are prone to fouling by waxes and asphaltenes. The issues needing to be addressed are the prevention of membrane fouling during operation and the provision of an expedient, cost-effective and non-hazardous means of cleaning fouled membranes. Currently, there are not enough existing studies related to the treatment of oilfield produced water using ceramic membranes.
\end{abstract}

Keywords: Oilfield produced water, ceramic membrane, water treatment, waste stream, membrane fouling, pressure-driven membrane processes, membrane cleaning.

\section{INTRODUCTION}

Oilfield wastewater known as produced water is generated in large quantities in onshore and offshore oil exploitation. On average, U.S. oil wells produce more than 7 billion barrels (bbl) of water for each barrel of oil. Moreover, water can comprise as much as $98 \%$ of the material brought to the surface from crude oil wells nearing the end of their productive lives [1]. According to the American Petroleum Institute (API), about $18 \mathrm{bbl}$ of produced water were generated by U.S. onshore operations in 1995 [2]. In the United Kingdom sector of the North Sea, the volume of produced water has exceeded crude oil volume since 1988 [3]. In 1996, 206 million tons of produced water was associated with a total crude oil production of 115.9 million tons [3]. In 1999, an average of 210 million bbl of water was produced elsewhere in the world each day [4].

Wastewaters from oilfields produced during many stages of crude oil production, recovery and transportation represent a major environmental and processing problem for the petroleum industry [5]. In addition, oil drilling operations can produce large quantities of contaminated water. These

*Address correspondence to these authors at the Institute of Biopharmaceutical Technology (IBPT), Department of Biotechnology/Biopharmaceutical Technology, University of Applied Sciences Giessen-Friedberg, Wiesenstrasse 14, 35390 Giessen, Germany; Tel: +49 641309 2551; Fax: +49 641 309 2553; E-mail: peter.czermak@tg.fh-giessen.de volumes represent huge amounts of contaminated water that require economical, environmentally friendly methods of treatment [6]. Furthermore, the water coming from the primary separation process (separation of wastewater from the oil) requires further treatment. Conventional treatment systems rely on: separation by gravity (skimmers and corrugated plate interceptors, or "CPI"), gas flotation, filtration and separation by centrifugal force (hydrocyclones) [7]. Generally, the produced wastewater should be reused for enhancing oil recovery or discharged into the environment after treatment. However, the characteristics of oily wastewater make it difficult to treat using commercial methods. Crude oil floating in the water can easily be removed by filtration or an alternate commercial system. Oil in water emulsions can be disposed of by chemical and physical treatments such as flotation column and centrifugation or by biological methods. Other components dissolved in the wastewater such as organic and inorganic substances, radionucleotides as specified below, and tiny oil drops are harmful to the environment and difficult to treat. Some components, including dissolved hydrocarbons, are highly toxic and difficult to break down in the environment.

If the wastewater is to be released as surface water, it must be treated to remove not only floating oil and suspended solids (SS) but virtually all of the dissolved components that contribute to the high chemical oxygen demand (COD) of the water as well [5]. There are several options for handling produced water including disposal, reinjection and 
treatment. The most popular option for handling produced water is to re-inject it back into the formation. Produced Water Re-Injection (PWRI) requires skillful planning to avoid formation damage yet it requires minimal or modified treatment before injection to meet the needed quality of reinjection water. Jun Wan et al. showed that treatment of produced water before re-injection gives better performance [8].

\section{CHARACTERISTICS OF OILFIELD PRODUCED WATER}

Produced water always contains a complex mixture of organic and inorganic materials similar to those found in crude oil and natural gas, whose compositions vary with the location and over the lifetime of a producing field [9]. Average levels of some critical organic and inorganic pollutants found in oilfield waters are shown in Table 1 [10-13]. The basic components can be grouped into the following categories:

- Organic substances including benzene, napthalene, toluene, phenantrene, bromodichlormethane, pentachlorphenol and free oil.

- $\quad$ Inorganic substances such as $\mathrm{Pb}, \mathrm{As}, \mathrm{Ba}, \mathrm{Sb}, \mathrm{SO}_{4}$, $\mathrm{Zn}$, total dissolved solids (TDS) up to $250000 \mathrm{ppm}$.

- Radionucleotides including $\mathrm{U}$ and Radium, respectively [14].

Generally, most of the produced wastewater is reused and reinjected into the underground for enhancing oil recovery after a certain treatment yet large amounts of produced wastewater are discharged directly into the environment. In recent years, the ecological problems connected with crude oil pollution have become apparent through the observed presence of oil derivatives in the environment as a result of the complex composition of produced water [9].

\section{AVAILABLE TECHNOLOGIES FOR PRODUCED WATER TREATMENT}

There are a number of methods used for produced water treatment, each having its respective advantages and disadvantages. No single technique currently used is suitable for all needs. In 1995 the American Petroleum Institute (API) made its recommendation for the best available technology for produced water management on offshore gas and oil installations as follows [6]:

\section{Carbon Adsorption (Modular Granular Activated Car- bon Systems)}

Advantages: Removes hydrocarbons and acid, base and neutral compounds; low energy requirements; higher throughput than other treatments (except biological); treats a broad range of contaminants; very efficient at removing high molecular weight organics.

Disadvantages: Fouling of carbon granules is problematic; produces waste stream of carbon and backwash; requires some pre-treatment of produced water stream.

\section{Air Stripping (Packed Tower with Air Bubbling Through the Produced Water Stream)}

Advantages: Removes $95 \%$ of volatile organic compounds (VOCs) as well as benzene, toluene, naphthalene, and phenols; $\mathrm{H}_{2} \mathrm{~S}$ and ammonia can be stripped with $\mathrm{pH}$ adjusting; higher temperature improves removal of semi-volatiles; small size; low weight and low energy requirements.

Disadvantages: Can be fouled by oil; risk of iron and calcium scale formation; generates an off-gas waste stream that may require treatment; requires some pre-treatment of produced water stream.

\section{Ultra-Violet Light (Irradiation by UV Lamps)}

Advantages: Destroys dissolved organics and both volatile and non-volatile organic compounds, including organic biocides; does not generate additional waste stream; handles upset or high loading conditions.

Disadvantages: Will not treat ammonia, dispersed oil, heavy metals, or salinity; relatively high energy requirements; UV lamps may become fouled; residues may be toxic if peroxide is used; requires some pre-treatment of produced water stream.

\section{Chemical Oxidation (Ozone and/or Hydrogen Peroxide Oxidation)}

Advantages: Removes hydrogen sulfide $\left(\mathrm{H}_{2} \mathrm{~S}\right)$ and particulates; treats hydrocarbons, acid, base and neutral organics, volatiles and non-volatiles; low energy requirements if peroxide system used; operation is straightforward.

Disadvantages: High energy inputs for ozone system; oil may foul catalyst; may produce sludge and toxic residues; requires some pre-treatment of produced water stream.

\section{Biological Treatment (Aerobic System with Fixed Film Biotower or Suspended Growth)}

Advantages: Treats biodegradable hydrocarbons and organic compounds, $\mathrm{H}_{2} \mathrm{~S}$, some metals and, in some conditions, ammonia; "fairly low" energy requirements; handles variable loadings, if acclimated.

Disadvantages: Large, heavy plant required for long residence times; build-up of oil and iron hinders biological activ-

Table 1. Characteristics of Oilfield Wastewaters: Organic Contents, Adapted from [15]

\begin{tabular}{|c|c|c|c|}
\hline \multirow{2}{*}{ Components } & \multicolumn{3}{|c|}{ Concentration (mg/L) } \\
\cline { 2 - 4 } & Norway [11] & Gulf of Mexico [12] & Campos Basin [15] \\
\hline \hline Benzene, Toluene, Xelyole (BTX) & 8 & B:1,318 & T:0,990 \\
\cline { 2 - 4 } & & $0,1,065: 0,135$ \\
\hline Naphthalenes & 5 & 1,049 & 0,106 \\
\hline Phenols & & $70-650$ & 4,3 \\
\hline Total organic carbons (TOC) & & & 386 \\
\hline
\end{tabular}


ity; aeration causes calcium scale formation; produces gas and sludge requiring treatment; requires some pre-treatment of feed.

\section{Membrane Filtration (Nanofiltration and Reverse Osmosis Polymeric Membranes)}

Advantages: Effective removal of particles, dispersed and emulsified oil; small footprint size; low weight and low energy requirements; high throughput rates.

Disadvantages: Doesn't remove volatiles or low molecular weight compounds; oil, sulfides or bacteria may foul membrane, which requires daily cleaning; effluent by-product may contain radioactive material; requires some pre-treatment of feed stream.

This recommendation, makes clear that required pretreatment of produced water stream (feed) is a major disadvantage of all treatment technologies. However, the combining of different technologies affords the possibility to reduce the pollutants in produced water to almost undetectable levels.

\section{MEMBRANE TECHNOLOGY FOR PRODUCED WA- TER TREATMENT}

Membrane filtration is a technology that has been successfully practiced for many decades and demonstrates obvious technical and economical feasibilities [16].

Overall, the membrane field has advanced immensely. Membranes are economical, environmentally friendly, versatile and easy to use, making them a leading choice for water purification applications which should continue to be the case for many years to come [17]. Membrane technology is widely accepted as a means of producing various qualities of water from surface water, well water, brackish water and seawater. Membranes are also used in industrial processes and wastewater treatment. Recently, membrane technology has been applied in the areas of secondary and tertiary municipal wastewater treatment and oil field produced water treatment [18]. Distinct advantages of membrane technology for treatment of produced water include reduced sludge, high quality of permease, and the possibility of total recycle water systems. These advantages coupled with the small space requirement, moderate capital costs and ease of operation associated with membrane technology make it a very competitive alternative to conventional technologies [19]. Pressure-driven membrane processes include microfiltration (MF), ultrafiltration (UF), nanofiltration (NF), and reverse osmosis (RO). MF and UF often serve to remove large organic molecules, large colloidal particles and microorganisms. MF performs as a porous barrier to reduce turbidity and some types of colloidal suspensions. UF offers higher removals than MF, but operates at higher pressure. UF can reject bacteria, macromolecules such as proteins and large particles and microorganisms. RO membranes exclude particles and even many low molar mass species, such as salt ions and organics.

Membranes are typically made from polymeric materials, ceramic (inorganic) though metal oxide membranes are also available and are traditionally used for ultrafiltration processes.

\section{CERAMIC MEMBRANES}

Porous ceramic membranes are an important membrane category that is of particular interest in applications requiring high chemical or thermal stability [20]. Tubular ceramic membranes are formed by a porous support (generally $\alpha$ alumina), one or more layers of decreasing pore diameter and an active or separating layer ( $\alpha$-alumina, zirconia, etc.) covering the internal surface of the tube (Fig. 1). Depending on the requirements of each particular application, a wide range of ceramic membrane designs (Fig. 2) and stainless steel membrane housing (Fig. 3) are commercially available. The use of ceramic membranes for microfiltration and ultrafiltration solutions is of great interest due to the potential to remediate fouling problems associated with those processes and solutions (adsorption or deposition of macromolecules on the membrane pores/surface) that strongly reduce volume flow and make the use of hard chemical and high temperatures in cleaning procedures necessary, which in turn causes damage to polymeric membranes [21].

\section{THE ADVANTAGES OF CERAMIC MEMBRANES}

- Narrow and well-defined pore size distribution, in comparison with their polymeric counterparts allows membranes to achieve a high degree of particulate removal at high flux as demanded by such diverse applications as the removal of emulsified oils from wastewaters.

- Material stability in harsh environments can provide cost-efficient high temperature deashing of spent lubricants and the removal of submicron suspended/dissolved solids from industrial solvents.

- Membrane cleaning with harsh chemicals (if necessary) does not reduce membrane performance stability, which is critical in dealing with waste streams that constantly vary or display a high propensity for membrane fouling [22].

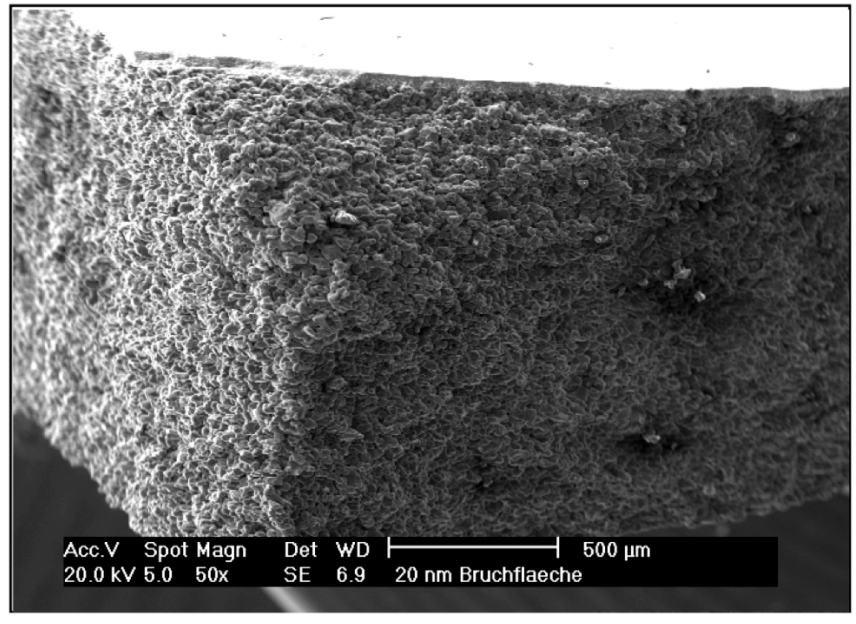

Fig. (1). Scanning electron microscopy picture of a ceramic membrane.

\section{PRODUCED WATER TREATMENT USING CE- RAMIC MEMBRANES}

In recent years, ceramic membranes have become popular due to their superior mechanical, thermal and chemical 


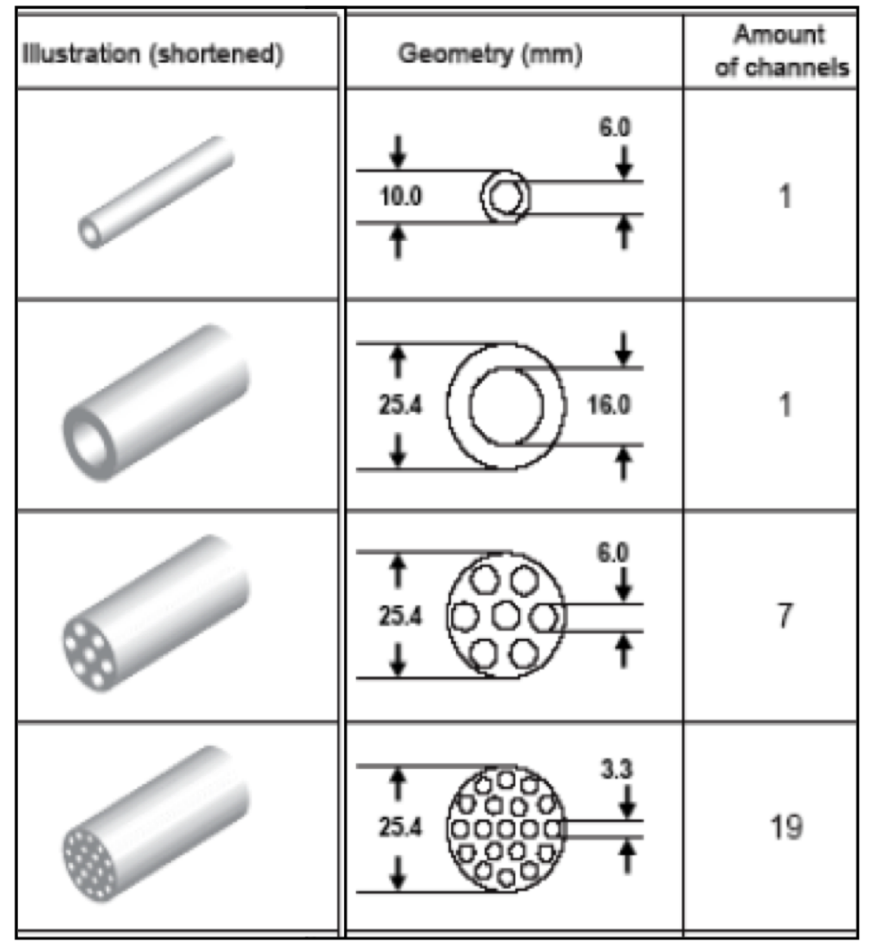

Fig. (2). Four different ceramic membrane designs, adapted from atech innovations $\mathrm{GmbH}$, Gladbeck, Germany.

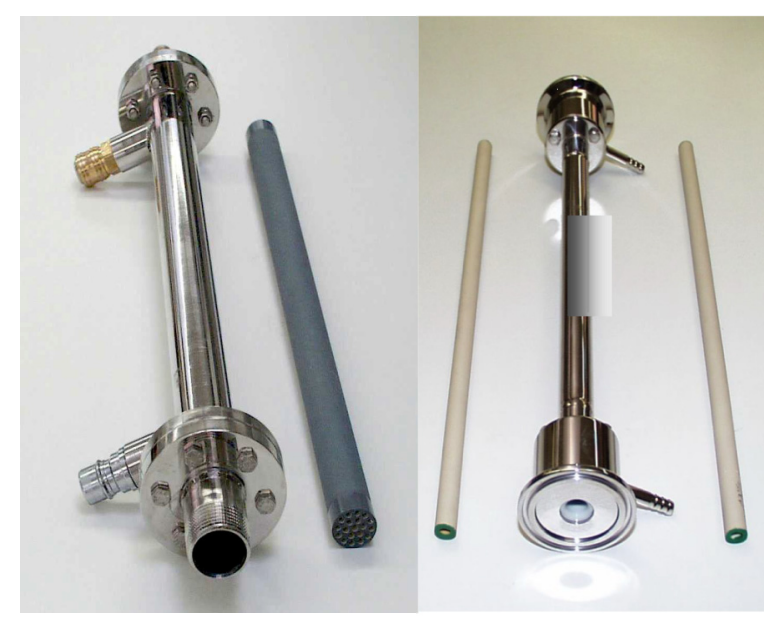

Fig. (3). Ceramic membranes and steel housings.

stability though their chemical selectivity and the available pore size range is limited. The use of ceramic UF membranes has not only grown in water treatment but also in the treatment of oil and detergent containing aqueous waste streams that are produced by various industrial operations (e.g. metal finishing, petroleum refining, bilge water treatment, railroad machining operations) [23]. In particular, ceramic UF membranes have been shown to be very effective in treating waste oil, grease and detergent-containing effluents with the purpose of removing oil contaminants while recycling the detergents. Ceramic membranes, particularly zirconia membranes, show better separation performance such as higher flux, less fouling and higher oil rejection than polymer membranes $[23,24]$. Aside from all these depicted benefits, one problem of water treatment using ceramic membranes lies in the reduced efficiency of ceramic UF membranes due to fouling by oily constituents and their resulting diminished lifetime [25].

\section{FLUX LOSS DUE TO MEMBRANE FOULING}

With the proven success of membranes in the water treatment arena, membrane technology continues to advance. Major problems still needing attention are membrane fouling and suitable cleaning strategies.

Reduced fouling would make membranes even more cost-effective by extending their operational lifetime and lowering their energy requirements. The permeate flux of a model solution (produced water from waste oil, $\mathrm{C}_{\mathrm{oil}}$ in feed: $5 \%$ ) as a function of time in the case of ultrafiltration experiments using two different ceramic membranes under continuous operation is shown in Fig. (4) [26].

During the membrane filtration process, permeate flux may decrease significantly and rapidly until a final steady state is attained at which the flux no longer decreases. The decline in flux is commonly connected to two phenomena: concentration polarization and fouling [27]. There are four major types of fouling:

Biofouling results from microbial contamination of feed water, producing a biofilm on the surface of the membrane which increases the resistance to water permeation through the membrane.

Scaling arises from the precipitation and deposition of salts on the membrane surface.

Organic fouling occurs when substances such as hydrocarbons coat the surface and/or plug pores in the porous support layer.

Colloidal fouling mainly results from particles such as clay or silica accumulating on the surface of the membrane.

Fouling can be controlled to some extent by adding disinfectants, anti-scaling agents, and other pre-treatment steps [28]. The level of membrane fouling depends on feed suspension properties (particle size, particle concentration, $\mathrm{pH}$, ionic strength), membrane properties (hydrophobicity, charge, pore size) and hydrodynamics (cross-flow velocity, transmembrane pressure) [29]. Also, the flux through UF membranes may be reduced due to concentration polarization, a problem more common to the use of UF than to other membrane processes due to the nature of the solutions being treated, i.e. organic components occurring in wastewater [30].

The feed flow velocity is a crucial parameter in controlling the flux. The choice of cross-flow velocity is usually a compromise between membrane performance (flux) and energy consumption. Flux increases linearly with pressure. A cross-flow velocity of $3 \mathrm{~m} / \mathrm{s}$ is normal; higher velocities further minimize the rate of fouling of the membrane surface, thereby maintaining a higher average flux. However, the use of overly high pressures may result in severe fouling and perhaps also membrane compaction. Therefore, there is an acceptable pressure range which should be adhered to for different membrane applications.

\section{CERAMIC MEMBRANE CLEANING METHODS}

Fouling is frequently cited as the most important factor limiting the utilization of membranes in produced water 


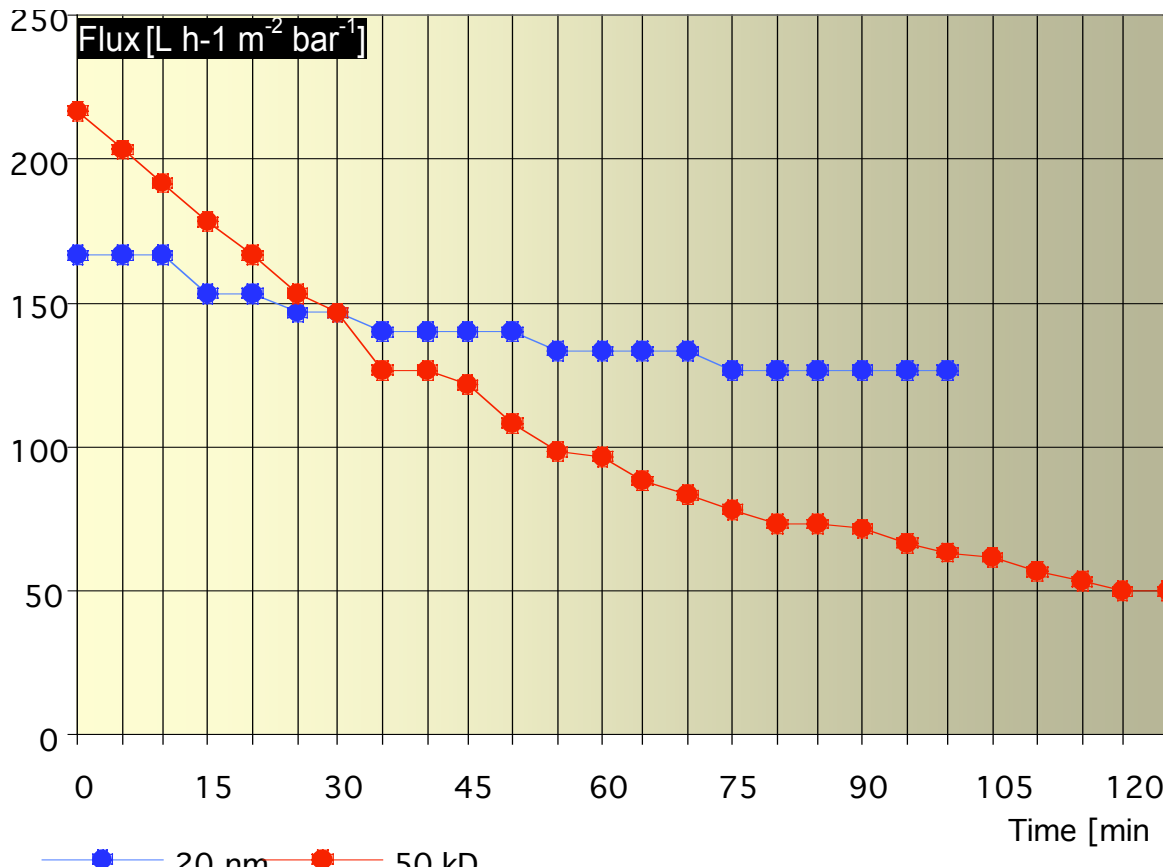

Fig. (4). Comparison filtrate flux of the $20 \mathrm{~nm}$ and $50 \mathrm{kDa}$ ceramic membranes. Model solution (produced water from waste oil) was used in a membrane-assisted continuous reactor at $30^{\circ} \mathrm{C}, \mathrm{TMP}=1$ bar.

treatment. Currently, the most commonly used methods to clean ceramic membranes and reduce membrane fouling include:

Cross-flushing in which the effect of a forward flush may be improved by the addition of air bubbles (AirFlush ${ }^{\circledR}$ ) [31].

Back flushing reverses the flow and permeate is flushed through the membrane pores. If components are strongly adsorbed onto the membrane, back flushing is usually not very effective.

Chemicals might be used to displace, to dissolve, or to chemically modify the foulants. The chemicals used for cleaning can be classified as follows [32]:

- Acids are used to dissolve calcium salts and metal oxides

- $\quad$ Alkalis are used to remove silica, inorganic colloids and many biological/organic foulants

- $\quad$ Surfactants are used to displace foulants, to emulsify oils and to dissolve hydrophobic foulants

- Oxidants are used for oxidation of organic material and bacteria (disinfection)

- $\quad$ Sequestrates (chelating agents) are used for removal of metal cations from a solution

- $\quad$ Enzymes are used to degrade foulants.

Ultrasound associated cleaning is performed at $45 \mathrm{kHz}$ or vibration at $50-1000 \mathrm{~Hz}$ of the module [33,34]. The use of ultrasound in conventional membrane filtration has recently come under investigation. Ultrasound increases the flux primarily by breaking the cake layer and by decreasing the solute concentration at the membrane surface.
Many studies of current membrane cleaning technologies include hydraulic, chemical, mechanical, and ultrasound associated methods have been reported [33-37]. Backwashing, a common hydraulic cleaning technique, is not ideal because it not only experiences degradation of flux between backwashes but requires a break in operation to be performed as well [38]. Problems with other cleaning techniques include chemical costs, waste disposal, and significant capital investments for equipment [39].

\section{PERFORMANCE STUDIES BY APPLICATION OF CERAMIC MEMBRANES FOR PRODUCED WATER TREATMENT}

Hua et al. studied the cross-flow microfiltration (MF) processes with oily wastewater using a ceramic $\left(\alpha-\mathrm{Al}_{2} \mathrm{O}_{3}\right)$ membrane with $50 \mathrm{~nm}$ pore size [40]. The influence of parameters such as trans-membrane pressure (TMP), crossflow velocity (CFV), oil concentration in feed on the separation behaviours were investigated by the measurements of permeate flux and total organic carbon (TOC) removal efficiency. In this study, the microfiltration process was successfully applied for the produced water treatment.

\section{Table 2a. Effects of TMP on Permeate Flux}

\begin{tabular}{|ccccc|}
\hline TMP $(\mathrm{MPa})$ & 0.05 & 0.1 & 0.15 & 0.2 \\
Flux $\left(\mathrm{Lm}^{-2} \mathrm{~h}^{-1}\right)$ & 30 & 70 & 110 & 170 \\
TOC removal efficiency (\%) & 97.3 & 97 & 95.2 & 93 \\
\hline
\end{tabular}

Experiment conditions were CFV: $1.68 \mathrm{~ms}^{-1}$, oil conc.: $500 \mathrm{mg} \mathrm{L}^{-1}(n=14)$, adapted from Hua et al. [40].

The high permeate flux was achieved under high TMP, high CFV and low oil concentration. The results also indicated that the permeate flux decreased either under high salt concentration or under low $\mathrm{pH}$ value in the feed solution. 
The TOC removal efficiencies were higher than $92.4 \%$ for all experimental conditions. The variations of permeate flux at TMP from 0.05 to $0.3 \mathrm{MPa}$ are shown in Table 2a. The steady permeate flux was highly dependent on TMP. It was also found that the increase of permeate flux under lower TMP was greater than that under higher TMP. When the TMP was greater than $0.2 \mathrm{MPa}$, the rate of increase of permeate flux was reduced. The effect of CFV on the permeation flux with the CFV ranged from 0.21 to $1.68 \mathrm{~ms}^{-1}$ is shown in Table $\mathbf{2 b}$. The results indicated that the higher $\mathrm{CFV}$ led to a higher steady permeate flux. This could be explained by the change of Reynolds number.

Table 2b. Effects of CFV on Permeate Flux

\begin{tabular}{|ccccc|}
\hline Cross flow velocity $\left(\mathrm{m} \mathrm{s}^{-1}\right)$ & 0.17 & 0.42 & 0.8 & 1.7 \\
Flux $\left(\mathrm{L} \mathrm{m}^{-2} \mathrm{~h}^{-1}\right)$ & 122 & 135 & 140 & 165 \\
TOC removal efficiency (\%) & 97.5 & 97.4 & 97.5 & 97.4 \\
\hline
\end{tabular}

Experiment conditions were TMP: $0.2 \mathrm{MPa}$, oil conc.: $500 \mathrm{mg} \mathrm{L}^{-1}(n=14)$, adapted from Hua et al. [40].

Tompkins et al. report that the U.S. Navy has successfully developed a system capable of meeting oily wastewater discharge regulations [41]. This system uses dense-pack ceramic ultrafiltration membranes (full scale module with $11.2 \mathrm{~m}^{2}$ surface area) and produces approximately 374 liters of clean effluent acceptable for overboard discharge for every 379 liters of OWS (Oil/Water Separators) effluent processed. Permeate quality averaging less than $5 \mathrm{ppm}$ and below $15 \mathrm{ppm}$ has been achieved aboard ship $95 \%$ of the time.

A series of tests was performed to determine the relationship between the permeate flux rate and the associated fouling rate. The tests were conducted in a similar manner to that described above except that valves were used to throttle the permeate flow rate to constant values.

Table 3. Effect of Permeate Flux Rate On Membrane Fouling, Adapted from Tompkins et al. [41]

\begin{tabular}{|c|c|c|}
\hline Flux & Resistance Allowed & Estimated Lifetime \\
\hline$\left[\mathbf{L ~ m}^{-2} \mathbf{h}^{-1}\right]$ & {$\left[\mathbf{b a r} \mathbf{L}^{-1} \mathbf{~ m}^{-\mathbf{2}} \mathbf{h}^{-1}\right]$} & {$[\mathbf{h}]$} \\
\hline \hline 51 & 0.08 & 3.55 \\
\hline 76 & 0.05 & $>>2.5$ \\
\hline 102 & 0.04 & 3.8 \\
\hline 127 & 0.03 & 1.35 \\
\hline 153 & 0.02 & 200 \\
\hline
\end{tabular}

Results given in Table 3 indicate that maximum membrane life is achieved at permeate flow rates below 102 $\mathrm{L} \mathrm{m}^{-2} \mathrm{~h}^{-1}$ (lmh).

J. Zhong et al. studied the performance of MF using ceramic membranes combined with traditional chemical method-flocculation as pretreatment [42]. After flocculation, the effluents were treated with micro-filtration using zirconia membranes. The average membrane layer of the asymmetric microporous $\mathrm{ZrO}_{2}$ membranes was about $30 \mu \mathrm{m}$ thick and the nominal pore size was $0.2 \mu \mathrm{m}$. The membrane elements were placed in $20 \mathrm{~cm}$ long stainless steel housing.

Table 4. MF Results With and Without Flocculation Pretreatment with Ceramic Membrane, Adapted from Zhong et al. [42]

\begin{tabular}{|c|c|c|}
\hline & MF & Flocculation+MF \\
\hline \hline Flux $\left(\mathrm{L} \mathrm{m}^{-2} \mathrm{~h}^{-1}\right)$ & 120 & 173.5 \\
\hline $\operatorname{COD}\left(\mathrm{mg} \mathrm{L}^{-1}\right)$ & 154 & 108 \\
\hline Oil content $\left(\mathrm{mg} \mathrm{L}^{-1}\right)$ & 34.68 & 8.762 \\
\hline
\end{tabular}
pressure: $0.110 \mathrm{MPa}$, cross-flow velocity: $2.56 \mathrm{~m} / \mathrm{s}$, operation temperature: $25^{\circ} \mathrm{C}$.

The results of filtration tests show that the membrane fouling decreased and the permeate flux and permeate quality increased with flocculation as pre-treatment (Table 4). The permeate obtained from flocculation and micro-filtration using $0.2 \mu \mathrm{m} \mathrm{ZrO}_{2}$ membrane is second only to that obtained after MF alone and meets the Chinese National Discharge Standard. The effects of process parameters including flocculation conditions, filtration conditions, etc. on the quality of effluent are also investigated.

Mueller et al. studied two $\alpha$-alumina ceramic membranes (0.2 and $0.8 \mu \mathrm{m}$ pore sizes) for the treatment of oily water containing various concentrations (250-1000 ppm) of heavy crude oil from Hueneme field in California [19]. This crude oil was added to various concentrations of top water. Each ceramic membrane has $35 \%$ porosity and an asymmetric surface layer of 4-5 $\mu \mathrm{m}$ thickness. They have a tubular geometry, with an i.d. of $0,7 \mathrm{~cm}$, a useful length of $20.6 \mathrm{~cm}$ and a surface area of $45.3 \mathrm{~cm}^{2}$. The membranes carried a negative charge of $\mathrm{pH}$ levels typical of produced water $(6,6-7,8)$. Table 5 shows the results derived from the two $\alpha$-alumina ceramic membranes. Increased oil concentrations in the feed decreased the final flux whereas the cross-flow rate, the trans-membrane pressure, and the temperature appeared to have relatively little effect on the final flux. Total resistance versus time curves from the flux decline data were used to identify the fouling mechanisms. The 0.2 and $0.8 \mu \mathrm{m}$ ceramic membranes appeared to exhibit internal fouling followed by external fouling.

\section{SUMMARY}

Every oilfield is characterized by a concomitant presence of fossil water and gas that come to the surface during oil extraction. The separated water, called "produced water" in the scientific literature, accounts for the majority of the waste derived from the production of crude oil.

Produced-water is always cleaned to some extent and the level of cleaning is dependent upon the intended use and/or current discharge regulations. Current technologies used consist of clarifiers, dissolved air flotation, hydrocyclones, and disposable filters/absorbers. After a primary process of separation from the oil, these technologies leave the water containing drops of oil in emulsion in concentrations as high as $2000 \mathrm{mg} / \mathrm{l}$, requiring the produced water to be further treated before it can be discharged.

Existing technologies are not typically capable of reaching the new levels of cleanliness demanded by regulations 
without using additional expensive chemicals for coagulation, settling and the like, which increases operating expenses and produces greater volumes of hazardous wastes. The international standards demand more efficient separation systems than those now in common use.

Table 5. Summary of the Results Derived from the Two Microfiltration Ceramic Membranes

\begin{tabular}{|c|c|c|c|c|}
\hline \multicolumn{5}{|c|}{$0.8 \mu \mathrm{m}$ Ceramic } \\
\hline Initial Flux & Final Flux & $\begin{array}{c}\text { Flux } \\
\text { Change }\end{array}$ & $C_{\text {oil }}$, Feed & Oil Removal \\
\hline$\left[\mathrm{kg} \mathrm{m}^{-2} \mathrm{~h}^{-1}\right]$ & {$\left[\mathrm{kg} \mathrm{m}^{-2} \mathrm{~h}^{-1}\right]$} & [\%] & [ppm] & [\%] \\
\hline $678 \pm 51$ & $33 \pm 6$ & $-95 .-1$ & 250 & 99.9 \\
\hline $998 \pm 500$ & $40 \pm 22(\mathrm{o})$ & -95.6 & 250 & 99.7 \\
\hline $800 \pm 128$ & $46 \pm 6(+)$ & -94.2 & 250 & 99.3 \\
\hline $471 \pm 15$ & $26 \pm 11(\mathrm{o})$ & -94.5 & 1000 & 99.4 \\
\hline \multicolumn{5}{|c|}{$0.2 \mu \mathrm{m}$ Ceramic } \\
\hline $211 \pm 19$ & $32 \pm 13(0)$ & -84.8 & 250 & 98.2 \\
\hline $301 \pm 52$ & $25 \pm 6(\mathrm{o})$ & -91.7 & 1000 & 99.4 \\
\hline 305 & 312 & +1.6 & 250 & 98 \\
\hline 281 & 577 & +105.4 & 250 & 98.5 \\
\hline
\end{tabular}

In all cases, the permeate was of very high quality, containing $<6 \mathrm{ppm}$ total hydrocarbons.

The results are shown as an average of three repetitions, plus and minus one standard deviation, with + , - and o representing positive, negative, and insignificant differences, respectively, from baseline results at the $90 \%$ confidence level, adapted from Mueller et al. [19].

Ceramic membrane systems under nano- and ultrafiltration conditions have proven to be economically attractive for the treatment of produced waters with elevated concentrations of oil and low-to-middle diameters of the particles. The issues needing to be addressed are the prevention of membrane fouling by waxes and asphaltenes during operation and to provide an expedient, cost-effective, and non-hazardous means of cleaning the membranes when they become fouled.

There are several desirable characteristics attributable to the use of ceramic membranes for the treatment of oilfield produced water that need to be developed, including modification of the cake layer properties to provide a constant filtration resistance, rapid cleaning of hydrocarbon fouling of the ceramic membrane surface, and ideally, better handling of higher concentrations of hydrocarbons in the feed by the filtration membranes without fouling.

\section{REFERENCES}

[1] Lee R, Seright R, Hightower M, Sattler M, Cather M, McPherson B, Wrotenbery L, Martin D, Whitworth M. Strategies for Produced Water Handling in New Mexico, presented at the 2002 Ground Water Protection Council Produced Water Conference, 2002: Colorado Springs, CO; pp. 16-17.

[2] API, 2000, "Overview of Exploration and Production Waste Volumes and Waste Management Practices in the United States," prepared by ICF Consulting for the American Petroleum Institute, Washington, DC, May.

[3] United Kingdom Department of Trade and Industry, The Energy Report Oil and Gas Resources of the United Kingdom, 1997; 2.

[4] Khatib Z, P. Verbeek. Water to Value - Produced Water Management for Sustainable Field Development of Mature and Green Fields. J Petrol Technol, 2003 Jan; pp. 26-28.
[5] Li Q, Kang C, Zhang C. Waste water produced from an oilfield and continuous treatment with an oil-degrading bacterium. Proc Biochem 2005; 40: 873-877.

[6] American Petroleum Institute, a special two-day meeting. op. cit. See also: OSPAR. 1992b. PARCOM Recommendation $92 / 6$ on the best available technology for produced water management on offshore gas and oil installations; 1995; Brussels.

[7] Ciarapica FE, Giacchetta G. The treatment of produced water in offshore Rig: Comparison between Tradition Installations and Innovative Systems: 2003: The Fifth International Membrane Science \& Technology Conference, University of New South Wales, 2003 Nov: Sydney, Australia.

[8] Jun Wan X, Liu B, Bai Y, Liang S. Reinjection of Finely Disposed Produced-water Reduces Formation Damage in Low Permeability Zones, paper SPE 82234 presented at the 2003 SPE European Formation Damage Conference, The Hague, 13-14 May.

[9] Guiying L, Taicheng A, Jiaxin C, Guoying S, Jiamo F, Fanzhong C, Shanqing Z, Huijun Z. Photoelectrocatalytic decontamination of oilfield produced wastewater containing refractory organic pollutions in the presence of high concentration of chloride ions. J Hazard Mater 2006; B138: 392-400.

[10] Tellez GT, Nirmalakhandan N, Gardea-Torresdey JL. Evaluation of biokinetic coefficients in degradation of oilfield produced water under varying salt concentrations. Water Res 1995; 29: 1711-8.

[11] Hansen BR, Davies SRH. Review of potential technologies for the removal of dissolved components from produced water. Chem Eng. Res Des 1994; 72: 176-88.

[12] Stephenson MT. Components of produced water: a compilation of industry studies. J Pet Technol 1992; 44: 548-603.

[13] Farnand BA, Krug TA. Oil removal from oilfield produced water by cross flow ultrafiltration. J Can Pet Technol 1989; 28: 18-24.

[14] Cheryan M, Rajagopalan N. Membrane processing of oily streams. Wastewater treatment and waste reduction. J Membr Sci 1998; 151: 13.

[15] Campos JC, Borges RMH, Oliveira Filho AM, Nobrega R, Sant'Anna GL. Oilfield wastewater treatment by combined microfiltration and biological processes. Water Res 2002; 36: 95-104.

[16] Van-der-Bruggen B., Van decasteele C. Distillation vs. membrane filtration: overview of process evolutions in seawater desalination, Desalination 2002; 143: 207-218.

[17] Alyson S, Benny F. Fundamentals of Membranes for water treatment University of Texas at Austin, Available from: http:// texaswater.tamu.edu/readings/desal/Membranetechnology.pdf.

[18] Bjarne N. Developments in membrane technology for water tratmemt. Desalination 2002; 153: 355-360.

[19] Jeffrey M, Yanwei C, Robert HD. Crossflow microfiltration of oily water. J Membr Sci 1997; 129: 221-235.

[20] Pagana A, Stoitsas K, Zaspalis VT. Applied pilot-scale studies on ceramic membrane processes for the treatment of waste water streams. Global NEST J 2006; 8: 23-30.

[21] Mulder M. Basic Principles of Membrane Technology. Kluwer Academic Publishers, Dordrecht: The Netherlands, 1991.

[22] Richard J, Ciora, Jr, Paul KT. Liu Ceramic Membranes for Environmental Related Applications Fluid. Particle Separation Journal 2003; 5: 51-60.

[23] Higgins RJ, Bishop BA, Goldsmith RL. Proceedings of the 3rd International Conference on Inorganic Membranes; 1994 July; Worcester, MA; p. 447.

[24] Yang C, Zhang GS, Xu NP, Shi J. Preparation and application in oil-water separation of $\mathrm{ZrO}_{2} / \alpha-\mathrm{Al}_{2} \mathrm{O}_{3} \mathrm{MF}$ membrane. J Membr Sci 1998; 142: 235-243.

[25] Ron SF, Yoram C. Fouling-resistant ceramic-supported polymer membranes for ultrafiltration of oil-in-water microemulsions. J Membr Sci 2001; 185: 129-143.

[26] Czermak P, Ebrahimi M, Mund P, Bolduan P, Wickramasinghe RS: Efficient oil field water treatment - investigations on the use of ceramic ultra- and nanofiltration membranes, 5th IWA Specialised Conference on Assessment and Control of Micopollutants/Hazardous Substances in Water; 2007; Frankfurt, Germany.

[27] Huisman HI. Cross-flow microflltration of particle suspensions: The influence of hydrodynamics and physicochemical interactions, Thesis, Lund University, Sweden, 1988.

[28] Amjad Z. Ed. Reverse Osmosis: Membrane Technology, Water Chemistry, and Industrial Applications; Van Nostrand Reinhold, New York: USA, 1993. 
[29] Bilstad T, Espedal E. Membrane separation of produced water War. Sci Tech 1996: 34, No. 9: 239-246.

[30] McCoy D Mac NJ. Membrane Separation Technologies, Standard Handbook for Hazardous Waste Treatment and Disposal, H.M. Freeman, ed., McGraw-Hill, New York: USA, 1988.

[31] Verberk JQJC, Hoogeveen PE, Futselaar H, Dijk JCV (2002). Hydraulic distribution of water and air over a membrane module using AirFlush., Water Science and Technology: Water Supply, 2002; 2: 297-304.

[32] Zeman LJ, Zydney AL. Microfiltration and ultrafiltration: principles and applications. Marcel Dekker, New York: USA, 1996.

[33] Chai X, Kobayashi T, Fujii, N. Ultrasound-associated cleaning of polymeric membranes for water treatment. Separation and Purification Technology, 1999; 15: 139-146.

[34] Vigo F, Uliana C, Ravina E, Lucifredi A, Gandoglia, M. The vibrating ultrafiltration module. Performance in the $50-1000 \mathrm{~Hz}$ frequency range. Separation Science and Technology 1993; 28 (4): 1063-1076.

[35] Lee H, Amy G, Cho J, Yoon Y, Moon SH, Kim IS. Cleaning strategies for cleaned flux ratio of an ultrafiltration membrane fouled by natural organic matter. Water Res 2001; 35: 3301.

[36] Liikanen R, Yli-kuivila J, Laukkanen R. Efficiency of various chemical cleanings for nanofiltration membrane fouled by conventionally treated surface water. J Membr Sci 2002; 195: 265.
[37] Van Paasen JAM, Kruithof JC, Bakker SM, Kegel FS. Integrated multi-objective membrane systems for surface water treatment: pre-treatment of nanofiltration by riverbank filtration and conventional ground water treatment. Desalination 1998; 188: 239.

[38] Lee SM, Jung JY, Chung YC. Novel method for enhancing permeate flux of submerged membrane systems in two-phase anaerobic reactor, Water Res 2001; 35: 471.

[39] American water works association, Water quality and treatment: Handbook of community water supplies, McGraw-Hill, New York, 1990.

[40] Hua FL, Tsang F, Wang fJ, Chan SY, Chua H, Sin SN. Performance study of ceramic microfiltration membrane for oily wastewater treatment. Chem Eng J 2007; 128: 169-175.

[41] Tompkins KT, Murphy LP, Owsenek BL, Pignataro RP, Rodriguez AT. Ultrafiltration Membrane polishing system for shipbord Treatment of oily wastwater. Naval Sea systems Command (SEA 03R16) Crystal City, VA 22242, Available from: http://www. p2pays.org/ref/21/20781.pdf.

[42] Jing Z, Xiaojuan S, Cheli W. Treatment of oily wastewater produced from refinery processes using flocculation and ceramic membrane filtration. Separation and Purification Technology 2003; 3.

(C) Ashaghi et al.; Licensee Bentham Open.

This is an open access article distributed under the terms of the Creative Commons Attribution License (http://creativecommons.org/licenses/by/2.5/), which permits unrestrictive use, distribution, and reproduction in any medium, provided the original work is properly cited. 